\title{
Derivation of keratinocyte progenitor cells and skin formation from embryonic stem cells
}

\author{
DANIEL ABERDAM* \\ INSERM U634, Faculté de Médecine, Nice, France
}

\begin{abstract}
Despite numerous elegant transgenic mice experiments, the absence of an appropriate in vitro model system has hampered the study of the early events responsible for epidermal and dermal commitments. Embryonic stem (ES) cells are derived from the pluripotent cells of the early mouse embryo. They can be expanded infinitely in vitro while maintaining their potential to spontaneously differentiate into any cell type of the three germ layers, including epidermal cells. We recently reported that ES cells have the potential to recapitulate the reciprocal instructive ectodermal-mesodermal commitments, which are characteristic of embryonic skin formation. Derivation of epidermal cells from murine ES cells has been successfully established by exposing the cells to precisely controlled instructive influences normally found in the body, including extracellular matrix and the morphogen BMP-4. These differentiated ES cells are able to form, in culture, a multilayered epidermis coupled with an underlying dermal compartment similar to native skin. This bioengineered skin provides a powerful tool for studying the molecular mechanisms controlling skin development and epidermal stem cell properties.
\end{abstract}

KEY WORDS: mouse, embryonic stem cell, epidermal lineage, BMP-4, skin, mesenchyme

\section{Pluripotent embryonic stem cells}

Embryonic stem (ES) cells are pluripotent cells derived from the inner cell mass of early mouse embryos. They can be propagated stably in an undifferentiated state in vitro in the presence of the cytokine leukemia inhibitory factor (LIF) without losing their pluripotency and their stable karyotype (Bishop et al., 2002). Upon withdrawal of LIF, ES cell differentiation is induced upon aggregation of ES cells to form embryoid bodies (EB) from which the cells differentiate spontaneously into all cell types, representative of the three germ layers (Fig. 1A). One major challenge remains to control the random in vitro differentiation potential of ES cells toward a specific functionally distinct cell population. Many attempts have been made to enrich heterogeneous ES cell population for a particular lineage by manipulating the ES cells with selective medium conditions (Okabe et al., 1996), chemicals (Bain et al., 1996; Dani et al., 1997), addition of cytokines (Fairchild et al., 2000), selectable genetic markers (Muller et al., 2000; Marchetti et al., 2002), coculture with inactivated feeder layers (Kawasaki etal., 2000) or by the combination of the above factors (Lee et al., 2000). Among many others, cardiomyocytes (Muller et al., 2000), muscles (Rohwedel et al., 1994), neurons (Kawasaki et al., 2000), endothelial (Marchetti et al., 2002), chondrocytes (Hegert etal., 2002), adipocytes (Dani etal., 1997), insulin-secreting cells (Soria et al., 2000), hematopoietic cells (Fairchild et al., 2000), melanocytes (Yamane et al., 1999), oocytes
(Hubner etal., 2003) and male germ cells (Toyooka etal., 2003) have been obtained. The recent success in establishing human ES cell lines raised great promises for both basic research on early human embryo development and therapeutic potential but have also received much public attention because of legal and ethical issues. At least, in vitro differentiation of ES cells will undoubtedly allow production of bioengineered tissues to replace animals in the screening of drugs for their potential toxic and teratogenic effects on embryonic development (Prelle et al., 2002).

\section{Embryonic stem cells as a model for keratinocyte com- mitment}

The vertebrate skin is composed of an epidermis and a dermis which derive from embryonic ectoderm and mesoderm, respectively. The mammalian epidermis is an extraordinarily dynamic tissue that contains a subpopulation of epidermal stem cells which produce daughter transient amplifying cells that undergo few divisions before they differentiate and leave the basal proliferating layer. Despite accumulating data on in vivo skin lineage differentiation, mainly

Abbreviations used in this paper: BMP-4, bone morphogenetic protein-4; BMZ, basement membrane zone; EB, embryoid body; ECM, extracellular matrix; ES, embryonic stem cell; HNF, human normal fibroblasts, LIF, leukemia inhibitory factor.

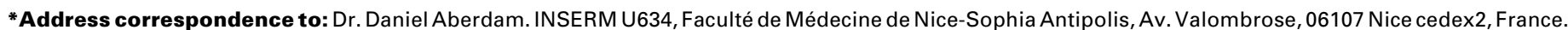
Fax: +33-4-9381-1404. e-mail: aberdam@unice.fr
} 
A

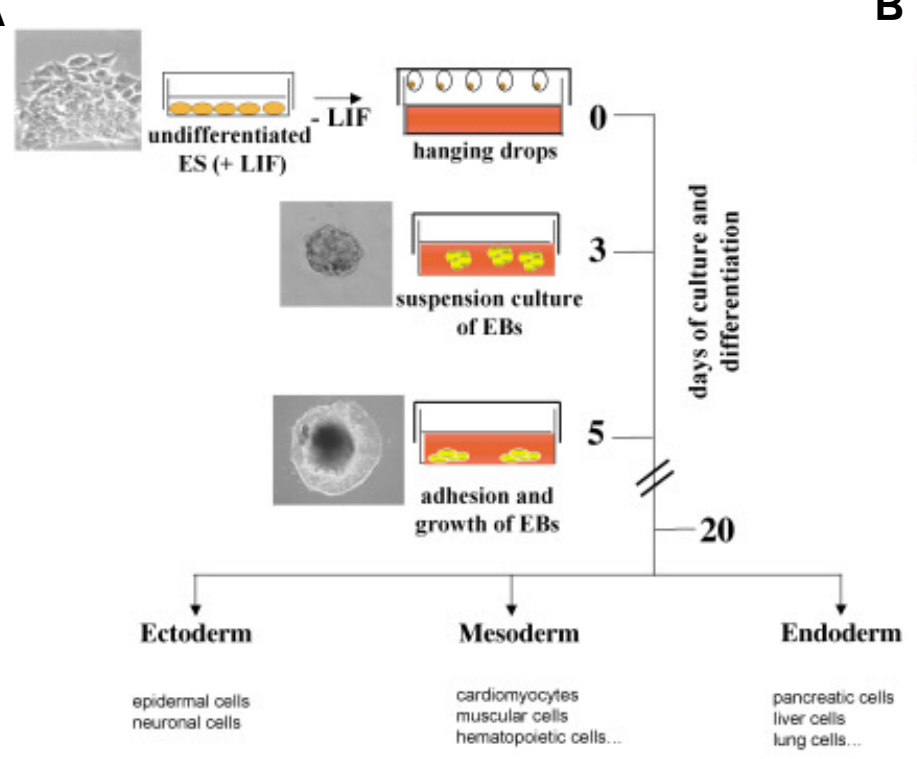

B

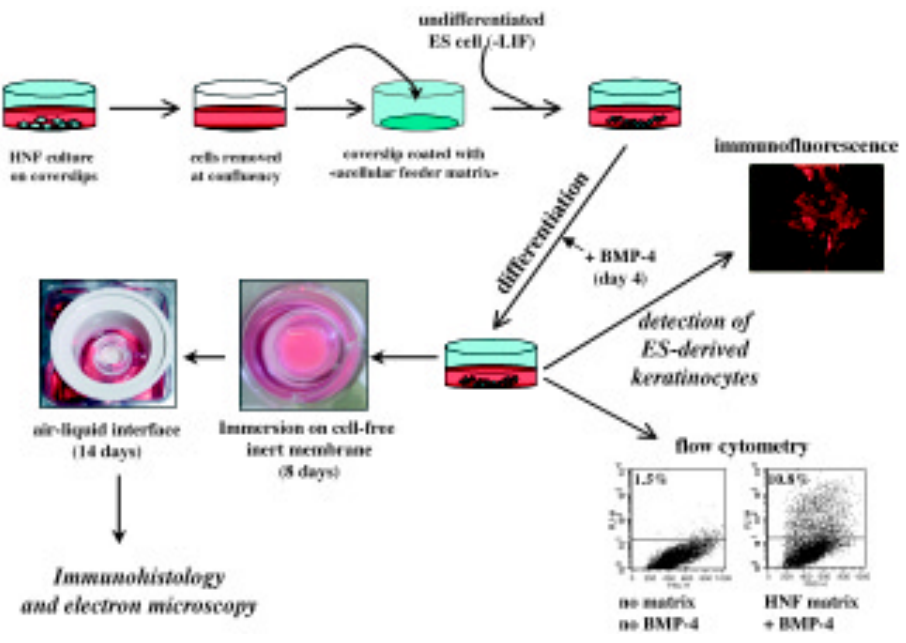

Fig.1. In vitro differentiation of ES cells: (A) by the "hanging drop" technique. After LIF removal, suspensions of ES cells are deposited on inverted covers for $72 \mathrm{~h}$. The resulting "hanging drops" form embryolike aggregates called embryoid bodies (EBs), consisting of derivatives of the three embryonic germ layers. Then, EBs are transferred into non-adherent Petri dishes for an additional 2 days in suspension. Finally, EBs are transferred into culture dishes for further differentiation. (B) as described in Coraux et al. (2003). HNF are cultivated on glass coverslips. At confluency, the cells are detached with a solution of EGTA/EDTA, allowing the secreted matrix proteins (and probably trapped growth factors and cytokines) to remain firmly attached to the culture support. Undifferentiated ES cells are seeded onto the "acellular feeder matrix" and induced to differentiate by removal of LIF from the medium. At day 4, ES cells plated on a HNF matrix are exposed to $0.5 \mathrm{nM}$ of BMP-4 for 3-10 days. The presence of ES-derived keratinocytes is scored using an antibody against the cytokeratin-14 intermediate filament. To test their capacity to produce a pluristratified epidermis, the induced ES cells are harvested and inoculated onto cellulose ester membranes for an additional week. The membranes are then mounted on stainless-steel grids to allow the surface of the cultures to be exposed to air. The cultures are incubated for an additional 14 days.

through transgenic technology (Koster et al., 2002), the absence of an appropriate in vitro model system has hampered the study of early events responsible for epidermal and dermal commitment. The in vitro differentiation of ES cells may provide an excellent model for studying the cellular and molecular mechanisms of early epidermal development and eventually the generation of donor cells for transplantation therapies. In 1996, F. Watt's group reported that EB differentiation recapitulates embryonic epidermal differentiation with the sequential appearance of epidermal markers (Bagutti et al., 1996). The K8/K18 pair, the first keratins to be expressed in simple epithelia during mouse development, were detected after 15 days in EB culture. Few days later, patches of K14-keratinocytes appeared in the EB culture. Although not observed by immunofluorescence, detection of transcripts for $\mathrm{K} 10$ and involucrin demonstrated the ability of EB to produce terminally differentiated keratinocytes (Bagutti et al., 1996). Lack of B1 integrin drastically affects the in vitro keratinocyte differentiation of EB but this failure can be reversed by addition of soluble KGF and FGF-10, two soluble factors secreted by dermal fibroblasts (Bagutti et al., 2001). This instructive effect of mesenchymal factors on epidermal commitment correlates well with the inductive role of mesodermal cells in ectodermal fate during embryonic skin development and in adult (Sengel, 1976).

Troy and Turksen reported the enrichment for epidermal cell population derived from ES by conditioning the EB culture with mouse keratinocytes isolated from K14 knock-out mice (Troy and Turksen, 2001). From the spontaneous differentiation of a single human embryoid body, $\mathrm{H}$. Green's group recently determined the successive appearance of specific markers expressed by commit- ted keratinocytes (Green et al., 2003).However, although spontaneous keratinocyte differentiation was reproducibly obtained from murine ES cells (Bagutti et al., 1996; Bagutti et al., 2001; Troy and Turksen, 2001), the nature of the stimuli necessary for such commitment remains totally unknown. The objective of our work was to use ES cells as a reproducible cellular model to identify the pathways involved in early skin formation. Because EB formation is not ideal for the analysis and control of the regulatory steps of induced differentiation, we tested the potential of ES cells to differentiate into epidermal cells without formation of EB. Our working hypothesis was that signals crucial for in vivo epidermal differentiation should be efficient to convert ES cells into keratinocytes.

Coordinated development of the ectodermal and mesodermal layers during morphogenesis is achieved by reciprocal signalling between these mutually dependent tissues (Sengel, 1976). In the reciprocal ectodermal-mesodermal interactions, the extracellular matrix (ECM) provides structural supports and directs a number of biological functions of adherent cells, such as cellular proliferation, migration and differentiation. Undifferentiated ES cells were seeded on slides coated with acellular ECM secreted by numerous primary cultures and cell lines of various origins (Fig. 1B). The most efficient keratinocyte induction was obtained when ES cells were seeded on matrix derived from human normal fibroblasts (HNF) and NIH-3T3 cells, both of mesenchymal origin (Coraux et al., 2003). Compared to EB formation in which keratinocytes appear at day 21, our culture model allows formation of K14positive cells as early as 8 days after induction. Enhancement of keratinocyte commitment was clearly observed when exogenous 
Bone Morphogenetic Protein-4 (BMP-4) was added from the fourth through the eighth day of culture (Fig. 1B) (Coraux et al., 2003). BMPs are members of the transforming growth factor- $\beta$ superfamily. During amphibian and chick gastrulation, when ectodermal cells choose between neural and epidermal fates, BMP-4 promotes epidermal commitment in the ventral zone while the production of dorsal BMP-4 antagonists by the SpemannMangold organizer allows neurogenesis (Munoz-Sanjuan and Brivanlou, 2002). Similar inductive activities are present in all vertebrate species since BMP-4 inhibits neural differentiation of ES cells (Kawasaki et al., 2000) and incubation of P19 embryonal carcinoma cells with BMP-4 increases the expression of epidermal cytokeratins (Glozak et al., 1996). Moreover, later in development, BMP-4 plays pivotal roles in the morphogenesis of cutaneous appendages (Wilson and Hemmati-Brivanlou, 1995). Our data suggest that factors present within the feeder matrix are required for ectodermal lineage commitment before ES cells make the neural-epidermal binary decision in a BMP-4 dependent manner. With cytometry studies and double immunofluorescence staining specific for cleaved caspase-3 and neural markers, we further showed that BMP-4 enhances keratinocyte differentiation, in part by inhibiting neural differentiation, through the apoptosis of the cells engaged in the neural pathway (unpublished data).

\section{Embryonic stem cell model for skin formation}

We observed that, upon induction, the ES-derived keratinocytes were almost exclusively located within patches on the top of surrounding cells. This suggests that local microenvironment effects of neighbouring cells are crucial for keratinocyte commitment, as already discussed elsewhere (Bagutti et al., 2001). Proliferating keratinocytes in culture have the ability to undergo terminal differentiation and form an epidermis-like tissue (Smola et al., 1998). Therefore, we tested the potential of the stimulated ES cells to produce a pluristratified epidermal tissue by using an organotypic culture model where the cells were cultured on a cell-free inert filter substrata at the air-liquid interface (Fig. 1B) (Coraux et al., 2003). Histological and indirect immunofluorescent staining of the organotypic culture of differentiated ES cells revealed the constitution of a skin, quite similar to a native mouse skin with both epidermal and dermal compartments (Fig. 2). Cytokeratins $\mathrm{K} 14$ and $\mathrm{K} 10$ were present in the respected epidermal layers (Fig. 2B and Coraux et al., 2003) while collagen IV, VII, laminin-1, -5 , integrin $\alpha 6 \beta 4$, fibronectin and nidogen were detected, as expected, at the basement membrane zone (BMZ) (Fig. 2 B,C and Coraux et al., 2003). Since nidogen was demonstrated to be exclusively produced by dermal fibroblasts during the early stage of dermal-epidermal formation (Smola et al., 1998), its presence along the ESderived $\mathrm{BMZ}$ and faintly in the cytoplasm of the underlying cells demonstrated that the underlying cellular compartment was composed of fibroblasts (Fig. 2C). Laminin-1 is normally deposited only in the presence of fibroblasts (Smola et al., 1998). Its accumulation along the $\mathrm{BMZ}$ and within the bottom layer suggested further the predominantly mesenchymal origin of the underlying cells (Coraux et al., 2003).

Electron microscopy analysis demonstrated that the ES-derived reconstituted skin displayed ultrastructural features of normal BMZ, including hemidesmosome condensations associated with keratin filament bundles, subbasal dense plaques, anchoring filaments and anchoring fibrils (Fig. 2D).

Altogether, these results demonstrate the remarkable potential of pluripotent ES cells to recapitulate many aspects of the embryonic skin formation in which mesodermal factors and BMP. 4 play a crucial role. Remarkably, this model reproduces the
A

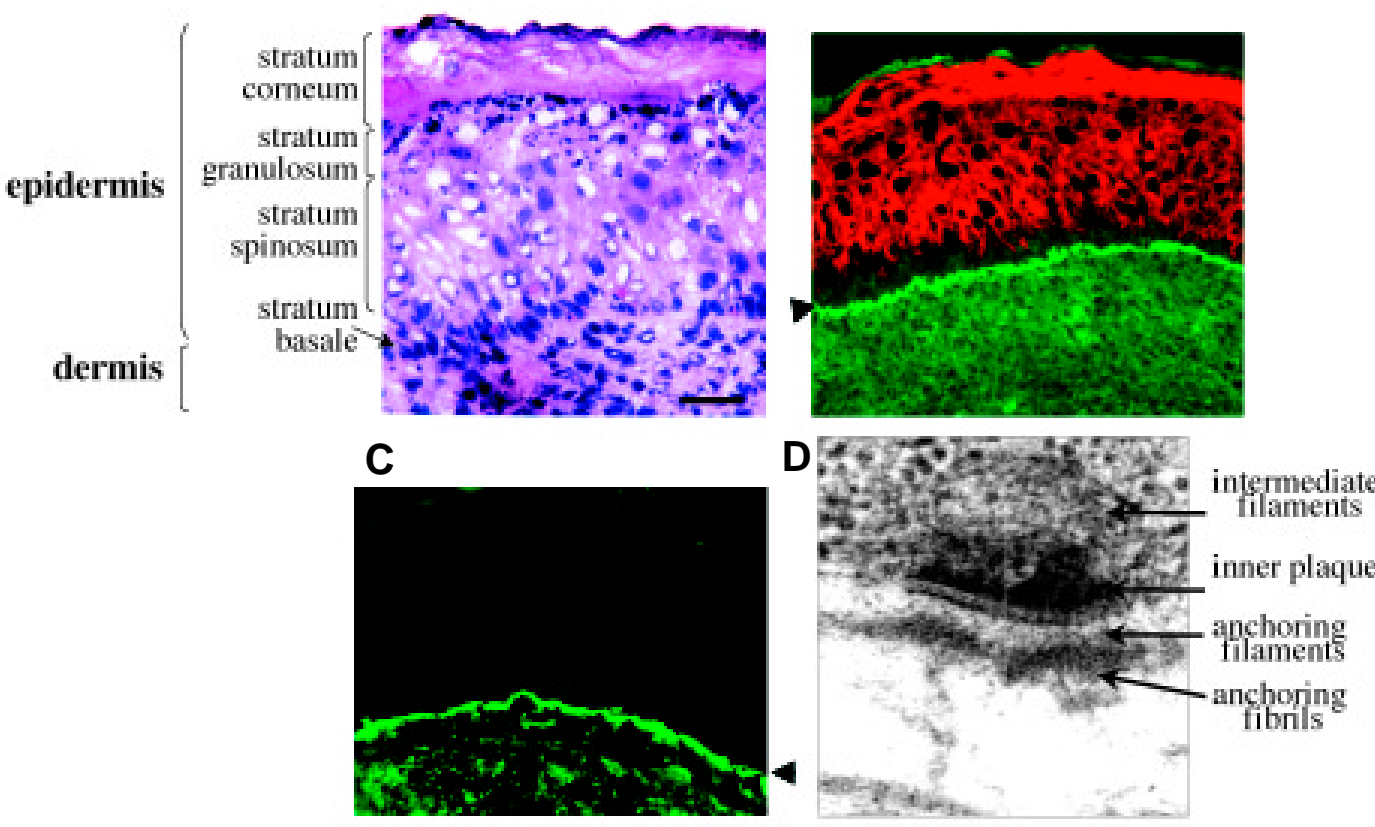

Fig. 2. ES-derived skin. (A) Histological staining shows the different layers of the epidermis, with a typical cuboidal cell-shape stratum basale, stratified suprabasal layers including a stratum spinosum, a stratum granulosum (containing keratohyalin granules) and a stratum corneum at the top. An underlying dermal compartment is clearly identified below the basal layer. Bar represents $11 \mu \mathrm{m}$. (B) All the macromolecules characteristic of each layer are present (see Coraux et al., 2003), and illustrated here by the immunostaining of cytokeratin 10 within the suprabasal layers (red) and type IV collagen at the dermalepidermal junction (green, arrowhead). (C) Nidogen is exclusively produced by the underlying dermal fibroblasts and deposited at the BMZ (green, arrowhead). (D) Electron micrograph of a hemidesmosomal anchorage structure from the ES-derived skin, with intermediate filaments, anchoring filaments and anchoring fibrils. Magnification: $x 50000$. 
tightly balanced process of both ectodermal and mesodermal proliferation, and terminal keratinocyte differentiation that both occur during skin organogenesis.

The in vitro skin organogenesis described herein provides a powerful system to characterize the molecular signals underlying the ectodermal-mesenchymal interactions during skin development by using for example genetically modified ES cells. A major challenge of in vitroES differentiation technology is the identification and characterization of intermediate cell population formed during the development of mature cell lineages. Presence of adult skin multipotent stem cells in the interfollicular epidermis, the hair follicule (bulge) and the sebaceous gland allows physiological renewal of the cutaneous epithelium and its appendages (Taylor etal., 2000; Oshima etal., 2001). These keratinocytes have a high self-renewal potential, as evidenced by clonogenicity tests and cellular transplantation (Potten and Booth, 2002). Unresolved questions still remain as to how, and to what extent, the differentiation commitment of cells derived from pluripotent ES cells is progressively restricted during development, and throughout adulthood. Do these cells give rise to adult stem cells with high proliferative and self renewal abilities, or are these cells in fact transit-amplifying progenitor cells, already engaged in terminal differentiation? Do these ES-derived cells have the multipotency characteristic of adult epidermal stem cells (Taylor et al., 2000; Oshima et al., 2001)? To address these questions, purified ESderived keratinocyte cell lines have to be isolated and characterized in vitroand in vivo. This approach might allow the identification of specific markers for skin stem cells which will be of great interest for the unlimited culture of patient-derived keratinocytes for autograft therapeutic purposes. These cell lines will also allow the investigation of the fascinating multipotential property of adult epidermal stem cells.

\section{References}

BAGUTTI, C., WOBUS, A. M., FASSLER, R. and WATT, F. M. (1996) Differentiation of embryonal stem cells into keratinocytes: comparison of wild-type and beta 1 integrin-deficient cells. Dev. Biol. 179: 184-196.

BAGUTTI, C., HUTTER, C., CHIQUET-EHRISMANN, R., FASSLER, R., WATT, F.M. (2001). Dermal fibroblast-derived growth factors restore the ability of beta(1) integrin-deficient embryonal stem cells to differentiate into keratinocytes. Dev. Biol. 231. 321-33.

BAIN, G., KITCHENS, D., YAO, M., HUETTNER, J.E. and GOTTLIEB, D.I. (1995). Embryonic stem cells express neuronal properties in vitro. Dev. Biol. 168: 342-57.

BISHOP, A.E., BUTTERY, L.D. and POLAK, J.M. (2002). Embryonic stem cells. J. Pathol. 197: 424-429.

CORAuX, C., HILMI, C., ROULEAU, M., SPADAFORA, A., HINNRASKY, J., ORTONNE, J.P., DANI, C. and ABERDAM, D. (2003). Reconstituted skin from murine embryonic stem cells. Curr. Biol. 13: 849-53.

DANI, C., SMITH, A.G., DESSOLIN, S., LEROY, P., STACCINI, L., VILLAGEOIS, P., DARIMONT, C. and AILHAUD, G. (1997). Differentiation of embryonic stem cells into adipocytes in vitro. J. Cel/ Sci. 110:1279-85.

FAIRCHILD, P.J., BROOK, F.A., GARDNER, R.L., GRACA, L., STRONG, V., TONE, Y., TONE, M., NOLAN, K.F. and WALDMANN, H. (2000). Directed differentiation of dendritic cells from mouse embryonic stem cells. Curr. Biol. 10:1515-8.

GLOZAK, M.A. and ROGERS, M.B. (1996). Specific induction of apoptosis in P19 embryonal carcinoma cells by retinoic acid and BMP2 or BMP4. Dev. Biol. 179: 458-470.

GREEN, H., EASLEY, K., IUCHI, S. (2003). Marker succession during the development of keratinocytes from cultured human embryonic stem cells. Proc Natl Acad $\mathrm{SCl}$ USA. 100: 15625-30.
HEGERT, C., KRAMER, J., HARGUS, G., MULLER, J., GUAN, K., WOBUS, A.M., MULLER, P.K. and ROHWEDEL, J. (2002). Differentiation plasticity of chondrocytes derived from mouse embryonic stem cells. J Cell Sci. 115: 4617-28.

HUBNER, K., FUHRMANN, G., CHRISTENSON, L.K., KEHLER, J., REINBOLD, R., DE LA FUENTE, R., WOOD, J., STRAUSS, J.F. 3RD, BOIANI, M. and SCHOLER, H.R. (2003). Derivation of oocytes from mouse embryonic stem cells. Science. 300: 1251-6.

KAWASAKI, H., MIZUSEKI, K., NISHIKAWA, S., KANEKO, S., KUWANA, Y., NAKANISHI, S., NISHIKAWA, S.I. and SASAI, Y. (2000). Induction of midbrain dopaminergic neurons from ES cells by stromal cell-derived inducing activity. Neuron 28:31- 40

KOSTER, M.I., HUNTZINGER, K.A. and ROOP, D.R. (2002). Epidermal differentiation: transgenic/knockout mouse models reveal genes involved in stem cell fate decisions and commitment to differentiation. J Investig Dermatol Symp Proc. 7 : 41-5.

LEE, S.H., LUMELSKY, N., STUDER, L., AUERBACH, J.M. and MCKAY, R.D. (2000). Efficient generation of midbrain and hindbrain neurons from mouse embryonic stem cells. Nat Biotechnol. 18: 675-9.

MARCHETTI, S., GIMOND, C., ILJIN, K., BOURCIER, C., ALITALO, K., POUYSSEGUR, J. and PAGES, G. (2002). Endothelial cells genetically selected from differentiating mouse embryonic stem cells incorporate at sites of neovascularization in vivo. J Cell Sci. 115: 2075-85.

MULLER, M., FLEISCHMANN, B.K., SELBERT, S., JI, G.J., ENDL, E., MIDDELER, G., MULLER, O.J., SCHLENKE, P., FRESE, S., WOBUS, A.M., HESCHELER, J., KATUS, H.A. and, FRANZ, W.M. (2000). Selection of ventricular-like cardiomyocytes from ES cells in vitro. FASEB J. 14: 2540-2548.

MUNOZ-SANJUAN, I. and BRIVANLOU, A. H. (2002). Neural induction, the default model and embryonic stem cells. Nat. Rev. Neurosci. 3: 271-280.

OKABE, S., FORSBERG-NILSSON, K., SPIRO, A.C., SEGAL, M. and MCKAY, R.D. (1996). Development of neuronal precursor cells and functional postmitotic neurons from embryonic stem cells in vitro. Mech Dev. 59:89-102.)

OSHIMA, H., ROCHAT, A., KEDZIA, C., KOBAYASHI, K. and BARRANDON, Y. (2001). Morphogenesis and renewal of hair follicles from adult multipotent stem cells. Cell. 104: 233-45.

POTTEN, C.S. and BOOTH, C. (2002). Keratinocyte stem cells: a commentary. $J$ Invest Dermatol. 119: 888-99.

PRELLE, K.,ZINK, N. and WOLF, E. (2002) Pluripotent stem cells: Model of embryonic development, tool for gene targeting and basis of cell therapy. Anat. Histol. Embryol. 31: 169-186.

ROCHE, E., BERNA, G., LEON-QUINTO, T., REIG, J.A. and MARTIN, F. (2000). Insulin-secreting cells derived from embryonic stem cells normalize glycemia in streptozotocin-induced diabetic mice. Diabetes 49: 157-62.

ROHWEDEL, J., MALTSEV, V., BOBER, E., ARNOLD, H.H., HESCHELER, J. and WOBUS A.M. (1994). Muscle cell differentiation of embryonic stem cells reflects myogenesis in vivo: developmentally regulated expression of myogenic determination genes and functional expression of ionic currents. Dev Biol. 164: 87-101.

SENGEL, P. (1976). Morphogenesis of skin. In Developmentaland cell biology series. Cambridge University Press. Abercrombie, H., Newth, D., Torrey, J.G. (Eds), pp. 1-269.

SMOLA, H., STARK, H. J., THIEKOTTER, G., MIRANCEA, N., KRIEG, T. and FUSENIG, N. E. (1998). Dynamics of basement membrane formation by keratinocyte-fibroblast interactions in organotypic skin culture. Exp. Cel/Res. 239: 399-410.

TAYLOR, G., LEHRER, M.S., JENSEN, P.J., SUN, T.T. and LAVKER, R.M. (2000). Involvement of follicular stem cells in forming not only the follicle but also the epidermis. Cell. 102: 451-61.

TOYOOKA, Y., TSUNEKAWA, N., AKASU, R. and NOCE, T. (2003). Embryonic stem cells can form germ cells in vitro. Proc Natl Acad Sci USA. 100: 11457-62.

TROY, T.C. and TURKSEN, K. (2001). Epidermal lineage. In Methods Mol Biol. 185 229-53, Edited K. Turksen, Humana Press Inc, Totowa, NJ.

WILSON, P. A. and HEMMATI-BRIVANLOU, A. (1995). Induction of epidermis and inhibition of neural fate by Bmp-4. Nature 376: 331-333.

YAMANE T., HAYASHIS., MIZOGUCHI M., YAMAZAKI H. and KUNISADA T. (1999). Derivation of melanocytes from embryonic stem cells in culture. Dev Dyn. 216: 450-8. 